\title{
VARIABILITY PATTERNS IN SOIL MOISTURE AND SOIL PH VALUES UNDER SANDY CANOPIES OF BLEPHARIS SINDICA T. ANDERS IN CHURU REGION - A PART OF INDIAN THAR DESERT
}

\author{
Purushottam Lal ${ }^{1}$ and Sher Mohammed ${ }^{2}$ \\ ${ }^{1}$ Assistant Professor Department of Botany, Govt. College, Dholpur (Rajasthan), India \\ ${ }^{2}$ Associate Professor Department of Botany, Govt. Lohia PG College, Churu (Rajasthan), India \\ Corresponding author Email: bansiwal.purush@gmail.com
}

\begin{abstract}
Soil parameters constitutively frame the edaphic environment for the naturally growing plants. Proper response to these dynamic parameters enables the plants to survive and reproduce. Blepharis sindica T. Anders (Acanthaceae) is a threatened medicinal plant of Indian arid zone and reported to grow with progressively declining patchy populations at sandy habitats in Churu region. Micro-environment especially edaphic characteristics, under the canopies of plants impact largely on plant development. In the present study an attempt has been made to evaluate yearlong variations in soil moisture contents (as percentage value) and soil $\mathrm{pH}$ at natural sandy sites of this threatened species. Values were estimated for both surface soil $(0-5 \mathrm{~cm})$ and depth soil $(20-25 \mathrm{~cm})$ layers under plant canopies. Data revealed that moisture percentage values remain higher only in rainy months that support seed germination and subsequent vegetative growth of plants. Progressive decline in soil moisture contents as well as increase in soil $\mathrm{pH}$ during late growing season seems to exert their effect as culmination of growth in this species.
\end{abstract}

Key words: Soil Moisture, pH, Arid Zone, Rain Fall, Sandy Areas, Medicinal, Threatened

\section{Introduction}

Soils form the heart of the Earth's "critical zone", on which living beings mostly rely for their various resource requirements. Physically, it is an extra-ordinary complex that controls carbon, nutrients and water cycling (Brantley, 2010). The sustainable productivity of a soil mainly depends upon its ability to supply essential nutrients to the growing plants (Chaudhari and Ahire, 2013). Organisms in the soil food web decompose soil nutrients and make them available to plants (Brussaard et al., 2007). The rate of soil nutrient decomposition and turnover mainly depends upon the interplay between soil biota, temperature, moisture and soil chemical and physical composition (Taylor et al., 2009). Optimum plant growth and crop yield depend not only on total amount of nutrients present in the soil at a particular time but also on their availability, which in turn, is controlled by physico-chemical properties such as soil texture, organic carbon, cation exchange capacity, $\mathrm{pH}$, etc.

The suitability of soil as a medium of plant growth depends on both its chemical and physical properties. The adverse physical soil environment conditions limit root growth and root activity that manifest reduced nutrient absorption and plant growth (Chaudhary and Sandhu, 1983; Peterson et al., 1984). As per Rodriguez-Iturbe and Porporato (2004), soil is the primary store and regulator in the water flow of ecosystems, by intercepting precipitation input and controlling its use by organisms, especially by plants. Soil moisture is a comprehensive indicator in hydrological processes and ecosystems functioning (Chang and Wetzel, 1991). Soil moisture availability primarily influences plants by two routes, either by being directly limiting as a resource, or indirectly by filling pore spaces in soil and thereby excluding air, causing oxygen availability to become limiting for the activity of plant roots (Golhar and Chaudhari, 2013). Increased soil water concentrations positively affect nutrient input, decomposition, 
mineralization and physical transport of nutrients in soil, all of which should increase plantavailable nutrients (Schimel et al., 1997).

Soil $\mathrm{pH}$ depends upon a variety of factors including all soil-forming factors plus the season of the year, cropping practices, the soil horizon sampled, the water content at sampling time and the way $\mathrm{pH}$ is determined (Tisdale et al., 1995). The soil $\mathrm{pH}$ influences the rate of weathering processes, which in turn affect the solubility of many of the nutrients in the soil needed for proper plant growth and development (Evrendilek et al., 2004). The most universal effect of $\mathrm{pH}$ on plant growth is nutritional, as it determines the nutrient availability to plants (Hoffmann, 2010). Soil $\mathrm{pH}$ ranges facilitate a respective vegetation to grow, and in turn the growing vegetation influences the soil $\mathrm{pH}$ by organic matter production and leaching actions (Rowell, 1994).

Indian arid zone is a home of unique phyto-diversity including an array of medicinal plant species. Desertic conditions are life limiting for these plants and also determine their future. Blepharis sindica T. Anders is an IUCN declared threatened medicinal plant species of Acanthaceae family (UNDP, 2010) being locally known as Billi-khojio/Unt-kantalo/Bhangaro. The plants are medicinally important for aphrodisiac and invigorating benefits (Singh et al., 1996; Khare, 2007). During vegetative growth, $B$. sindica plants attain $10-55 \mathrm{~cm}$ above ground height with a characteristic dichotomously branching habit and seed loaded spikes at their nodes. The plants thrive well at sand dunes and undisturbed margins of field fencings (Lal et al., 2014). The growing season of the species starts with the seed germination in June last of early July as the first monsoon showers precipitate in the area. The plants culminate their life in form of dried lignified plants standing rooted in their natural sandy habitat in months of DecemberJanuary each year. The present study was aimed to investigate the yearlong variability in the levels of soil moisture (percent) and $\mathrm{pH}$ values underneath/nearby canopies of Blepharis sindica plants at two different selected sites in Churu region - a part of Indian Thar desert.

\section{Materials and Methods}

In the present study, two different study sites of $B$. sindica populations were selected in Churu region, viz. Shyampura village (Site-A; 28.2647533 N, 74.8945098 E) and Buntia village (Site-B; $28.3528630 \mathrm{~N}, 75.0090939 \mathrm{E})$. Climatic data from meteorological Centre, Jaipur revealed that various factors, viz. rainfall, temperature and humidity, showed great monthly variation and also influenced each other. Rainy months (July-August) were reported with highest amount of precipitation (up to $345 \mathrm{~mm}$ in August). In summer months (April-June), the area experiences high temperature peaks (up to $50^{\circ} \mathrm{C}$ in May) with frequent dust storms while in winter months (November-February) the temperature deeps as low as $-2^{0} \mathrm{C}$ (in January month). Besides rainy spells, the area faces low amount of relative humidity and high rates of evopo-transpirational loses.

Soil samples were collected from these sites beneath $B$. sindica plants (green plants in growing season, while dried plants in rest of the year) during July 2017 to June 2019. The soil samples were collected (in glass bottles fitted with air tight rubber caps) monthly from surface $(0-5 \mathrm{~cm})$ and $20-25 \mathrm{~cm}$ depth levels from above-mentioned sites and analyzed for moisture percent and $\mathrm{pH}$ parameters. The mean values of these parameters for two consecutive years are presented graphically and also in tabular forms. The soil moisture was estimated immediately after sampling was done, while $\mathrm{pH}$ was analyzed from air-dried samples sieved through $2 \mathrm{~mm}$ sieve. The percentage of soil moisture was measured on oven dry weight basis as described by Pandeya et al. (1968) and calculated as follows:

$$
\text { Soil moisture }(\%)=\text { - } \begin{gathered}
\text { Fresh weight }- \text { Oven dry weight } \\
\text { Oven dry weight }
\end{gathered}
$$


Soil $\mathrm{pH}$ was measured from water suspension of soil (1:5 ratio; $5 \mathrm{~g}$ soil: $25 \mathrm{ml}$ distilled water) using digital $\mathrm{pH}$ meter (Systronics) at room temperature. Results were subjected to analysis of variance as per Gomez and Gomez (1984) considering months as treatments and sampling position as replicates and affirmed significant or non-significant at $\mathrm{P}<0.05$.

\section{Results and Discussion}

Table 1 revealed that soil moisture (percent) values were observed highest during rainy months, i.e. July to September. Amongst both sites, the maximum values of soil moisture percentage (for surface and depth layers) were recorded for site-B. Maximum values for soil moisture percentage at surface layer was recorded in July (3.80 percent) while at depth soil layers, it was highest in August (6.39 percent).

Table 01: Mean Monthly Variations in Moisture Percentage at Surface $(0-5 \mathrm{Cm})$ and Depth (20-25 Cm) Soil Layers Collected Underneath of B. Sindica Plants from Sites - A \& B

\begin{tabular}{|c|c|c|c|c|}
\hline \multirow{2}{*}{ Month } & \multicolumn{2}{|c|}{ Site- A } & \multicolumn{2}{c|}{ Site- B } \\
\cline { 2 - 5 } Jul. & Surface soil & Depth soil & Surface soil & Depth soil \\
\hline Aug. & 3.65 & 2.15 & 3.80 & 2.64 \\
\hline Sep. & 1.68 & 4.94 & 2.22 & 6.39 \\
\hline Oct. & 2.21 & 5.23 & 1.23 & 6.11 \\
\hline Nov. & 0.49 & 3.10 & 0.39 & 2.10 \\
\hline Dec. & 1.03 & 3.47 & 0.72 & 2.68 \\
\hline Jan. & 0.55 & 3.26 & 0.51 & 2.28 \\
\hline Feb. & 3.00 & 3.52 & 1.44 & 4.99 \\
\hline Mar. & 1.93 & 3.79 & 1.84 & 4.06 \\
\hline Apr. & 0.64 & 2.28 & 0.62 & 3.42 \\
\hline May & 0.07 & 2.51 & 0.13 & 1.65 \\
\hline Jun. & 0.12 & 1.43 & 0.12 & 1.07 \\
\hline
\end{tabular}

At surface, the minimum values were observed in April for site-A (0.07 percent). In the month of May, the values (at both layers) were reported lowest (except site-A for surface layer; where it was reported lowest in April). Data were significant at $p<0.05$ from site-B for surface and from site-A for depth layers, while others were non-significant. In the present investigations, soil moisture values were highest during rainy months (July-September) followed by winter (November-February) and lowest during summer months (March-June) from both sites. The above results are in agreement with the studies of Sen (1982), Singh et al. (2005) and Gao-Lin et al. (2013), who observed soil moisture contents as a direct function of rainfall in the area. In the present studies, higher moisture amounts were recorded at depth $(20-25 \mathrm{~cm})$ levels suggesting the downward movement of water through capillary system and intensive water loss from surface soils by means of sun and wind being confirmative with the pattern recorded by Lal (2013) from Commiphora wightii habitats in western Thar desert.

Figure 01: Mean Monthly Rainfall (mm) in Churu Region during July 2017-June 2019

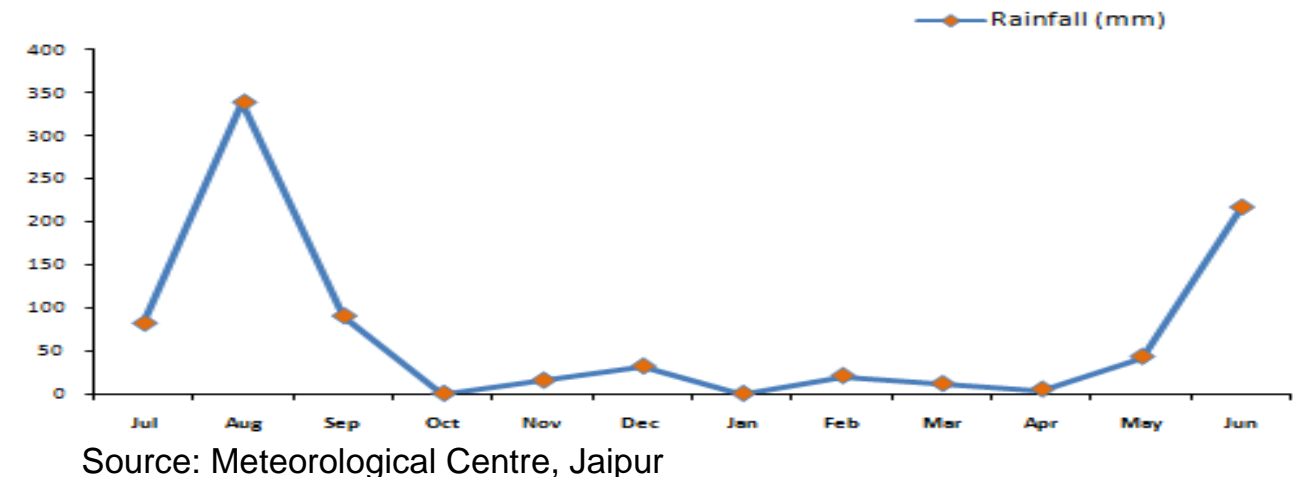

Source: Meteorological Centre, Jaipur 
The soil pH values at surface and depth layers varied slightly at both sites. Invariably the values were recorded highest during July and lowest in June for both layers (Table 2). Maximum values for surface (9.70) and depth (9.59) layer were observed during July from site-B, while minimum for surface (7.23) and depth (7.26) layers during June from site-A. Data were significant at $p<0.05$ for both layers at both sites.

Table 02: Mean Monthly Variations in Ph at Surface $(0-5 \mathrm{~cm})$ and Depth $(20-25 \mathrm{~cm})$ Soil Layers Collected Underneath of B. Sindica Plants from Sites - A \& B

\begin{tabular}{|c|c|c|c|c|}
\hline \multirow{2}{*}{ Month } & \multicolumn{2}{|c|}{ Site-A } & \multicolumn{2}{c|}{ Site-B } \\
\cline { 2 - 5 } & Surface soil & Depth soil & Surface soil & Depth soil \\
\hline Jul. & 9.39 & 9.36 & 9.70 & 9.59 \\
\hline Aug. & 7.75 & 7.77 & 8.03 & 8.14 \\
\hline Sep. & 7.79 & 7.81 & 8.06 & 7.93 \\
\hline Oct. & 7.54 & 7.55 & 7.87 & 7.90 \\
\hline Nov. & 7.55 & 7.54 & 7.73 & 7.73 \\
\hline Dec. & 9.15 & 9.24 & 9.38 & 9.43 \\
\hline Jan. & 9.13 & 9.21 & 9.38 & 9.35 \\
\hline Feb. & 8.11 & 8.14 & 8.37 & 8.41 \\
\hline Mar. & 8.19 & 8.16 & 8.41 & 8.45 \\
\hline Apr. & 7.54 & 7.61 & 7.60 & 7.64 \\
\hline May & 7.25 & 7.28 & 7.52 & 7.57 \\
\hline Jun. & 7.23 & 7.26 & 7.49 & 7.53 \\
\hline
\end{tabular}

Soil $\mathrm{pH}$ is an important measure because it functions as a useful predictor of various physio-chemical and biological activities within the soil. In its synergistic effect, it determines availability of soil nutrients for plants as well as microbial activities and physical conditions of the soil (Foth and Ellis, 1997). In Indian arid zone, majority of the soils are basic or slightly basic due to the presence of carbonate and bicarbonates. Abnormally high, more than 9 , and low or less than 4, are toxic to plants (Chundawat, 1990). Mehta (1992), Prakash (2001), Verma (2008) and Lal (2013) reported higher pH values during rainy periods underneath Acacia tortilis, Salvadora persica, Asparagus racemosus and Commiphora wightii, respectively. Fagbote and Olanipekun (2011) also observed maximum values of $\mathrm{pH}$ in rainy season in top soil of Ondo state (Nigeria). The present study also supports all the above mentioned researchers that highest $\mathrm{pH}$ values were during July for both surface and depth layers at both sites.

In the present studies, $\mathrm{pH}$ values were recorded higher at depth in comparison to surface layer, except during July, where they were higher at surface. These findings were supported by Ventura and Westanabe (1984) and Sharma et al. (2009), who had reported higher values with increasing soil depth. Increased $\mathrm{pH}$ values during July may be associated with possible hydrolysis of salts as a result of higher moisture content during this period. Thus, it is concluded from the present findings that values of soil moisture contents were higher at 20-25 $\mathrm{cm}$ depth layer as compared to surface from all sites. The $\mathrm{pH}$ values were greater at both layers during rainy months.

\section{Conclusion}

The present study reveals that soil moisture and $\mathrm{pH}$ values for both soil layers (surface and depth) varied significantly at both sites. The pattern of soil moisture percentage variability for surface soil was found in high correlation with rain fall trend in the area while moisture percentage values reported for depth layers of soil indicates its adjustment with that of evopotranspirational losses in the area. Soil $\mathrm{pH}$ values were found invariably higher in December January months being lower in rainy season only. The findings indicate that the soil $\mathrm{pH}$ values remain basic throughout the year. At the time of seed germination in the species, the adequate amount of soil moisture in both soil layers (surface and depth) as well as rainfall induced decrease in basic nature of soil seems to support seedling establishment at sandy sites of the area. The plants finish their life cycle as the $\mathrm{pH}$ values reaches to peak in December. As an 
essence, this threatened species of medicinal herb grows at its natural sites within a range of progressively decreasing trend of soil moisture contents and $\mathrm{pH}$ values standing around of value 8 (slightly basic).

Figure 02: Graphical presentation of mean monthly variations in soil moisture (Solid lines) and pH (bars) at surface $(0-5 \mathrm{~cm})$ and depth $(20-25 \mathrm{~cm})$ soil layers collected underneath of $B$. sindica plants from both sites (I and II for site-A; III and IV for site-B)
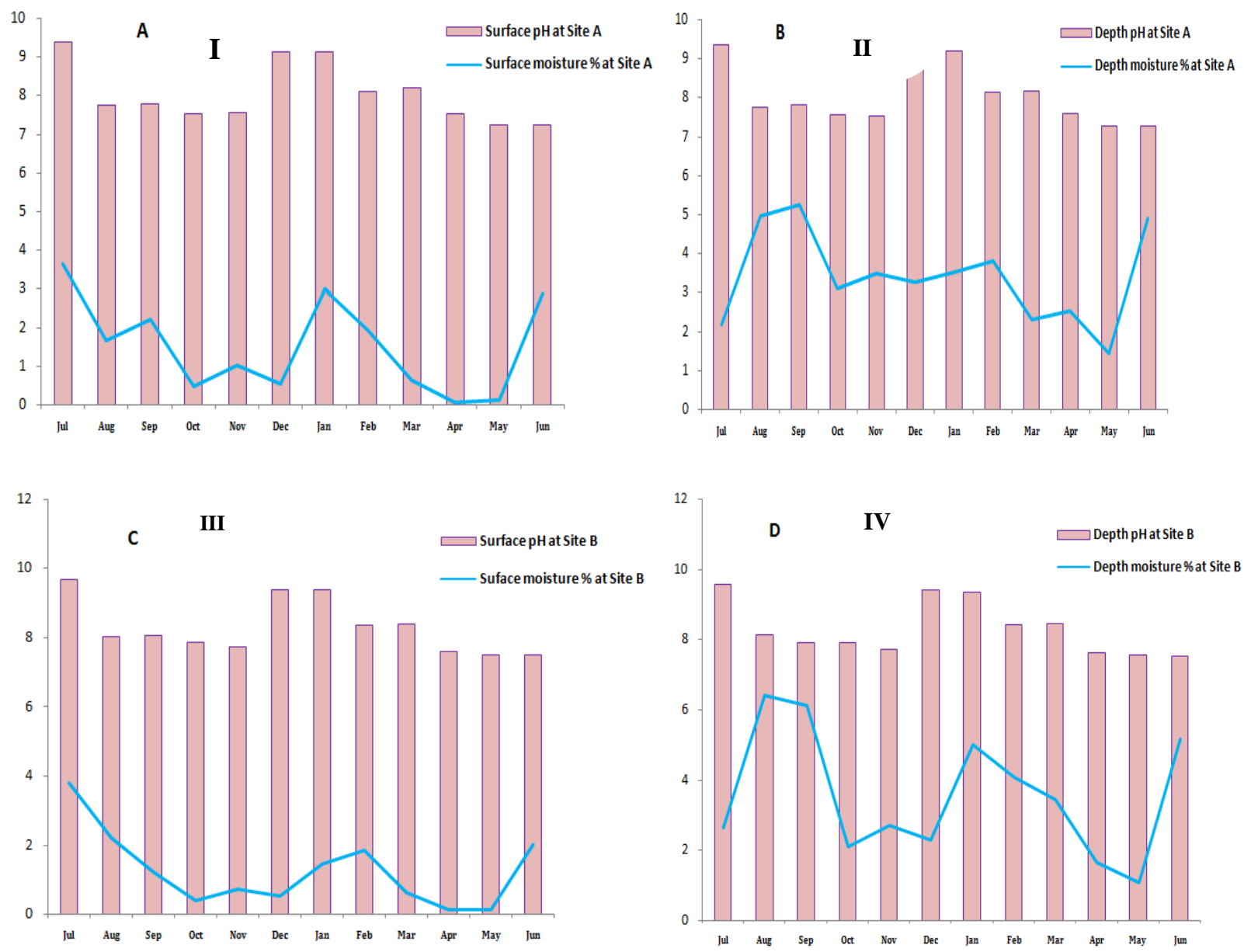

\section{References}

1. Brussaard, L., De-Ruiter, P.C. and Brown, G.G. (2007). Soil biodiversity for agricultural sustainability. Agric. Ecosyst. Environ. 121: 233-244.

2. Chang, J.T. and Wetzel, R.J. (1991). Effects of spatial variations of soil moisture and vegetation on the evolution of a prestorm environment: a numerical case study. Mon. Wea. Rev. 119: 13681390.

3. Chaudhari, P.R. and Ahire, D.V. (2013). Electrical conductivity and dielectric constant as indicators of available total macro and micro nutrients in the soil. Int. J. Phy. Math. Sci. 3: 13-17.

4. Chaudhary, T.N. and Sandhu, K.S. (1983). Soil Physical environment and root growth. Adv. Soil Sci. 1: 1-43.

5. Chundawat, B.S. (1990). Arid Fruit Culture. Oxford \& IBH Publishing Co. Pvt. Ltd., New Delhi, pp. 208.

6. Evrendilek, F., Celik, I. and Kilic, S. (2004). Changes in soil organic carbon and other physical soil properties along adjacent Mediterranean forest, grassland, and cropland ecosystems in Turkey. J. Arid Environ. 59: 743-752.

7. Fagbote, E.O. and Olainpekun, E.O. (2011). Seasonal and depth effects on the physicochemical parameters of the soils of farm settlements with bitumen deposit. Int. Res. J. Biotech. 2: 198-212.

8. Foth, H.D. and Ellis, B.G. (1997). Soil Fertility (2 ${ }^{\text {nd }}$ ed.). Lewis CRS Press LLC., USA, pp. 290.

9. Gao-Lin, W., Gao-Hua, R., Dong, W., Zhi-Hua, S. and David, W. (2013). Above and below ground responses to soil water change in an alpine wetland ecosystem on the Qinghai-Tibetan Plateau, China. J. Hydrol. 476: 120-127. 
10. Golhar, N.P. and Chaudhari, P.R. (2013). Level of significance of various physical and chemical parameters of soils through electrical conductivity. J. Chem. Bio. Phy. Sci. Sec. Section C: 3: 2051-2057.

11. Gomez, K.A. and Gomez, A.A. (1984). Statistical Procedures for Agricultural Research, (2 ${ }^{\text {nd }}$ ed.). John Wiley \& Sons, New York.

12. Hoffmann, H. (2010). Garden Note: Soil pH and Plant Health in Home Garden. Govt. of Western Australia, Department of Agriculture and Food, Australia, pp. 174.

13. Khare CP. 2007. Indian Medicinal Plants - An Illustrated Dictionary. Springer-Verlag, Berlin, New York, USA, p. 812.

14. Lal, H. (2013). Germplasm collection and propagation of Commiphora wightii (Arnot) Bhandari, an endangered medicinal plant of the Indian Thar desert. Ph.D. Thesis, J.N. Vyas University, Jodhpur, India.

15. Lal P, Mohammed S and Kasera P. K. (2014). High adaptability of Blepharis sindica T. Anders seeds towards moisture scarcity: A possible reason for the vulnerability of this medicinal plant from the Indian Thar desert. Journal of Research in Biology 4(2): 1293-1300.

16. Mehta, M. (1992). Biology and ecology of some desert trees and grasses in Indian desert. Ph.D. Thesis, J.N. Vyas University, Jodhpur, India.

17. Pandeya, S.C., Puri, G.S. and Singh, J.S. (1968). Research Methods in Plant Ecology. Asia Publishing House, London, UK, pp. 272.

18. Peterson, C.M., Klepper, B., Pumphrey, F.V. and Rickman, R.W. (1984). Restricted rooting decreases tiltering and growth of winter wheat. Agron. J. 76: 861-863.

19. Prakash, J. (2001). Biology of some medicinal plants in Indian arid zone. Ph.D. Thesis, J.N. Vyas University, Jodhpur, India.

20. Rodriguez-Iturbe, I. and Porporato, A. (2004). Eco-hydrology of Water controlled Ecosystems: Soil Moisture and Plant Dynamics. Cambridge University Press, Cambridge, UK. pp. 440.

21. Rowell, D.L. (1994). Soil Science: Methods and Applications. Addison Wesley Longman Singapore Publishers, England, UK, pp. 350.

22. Schimel, D.S., Vemap, P. and Braswell, B.H. (1997). Continental scale variability in ecosystem processes: Models, data and the role of disturbance. Ecol. Monogr. 67: 251-281.

23. Sen, D.N. (1982). Environment and Plant Life in Indian Desert. Geobios International, Jodhpur, India, pp. 249.

24. Sharma, G., Sharma, R. and Sharma, E. (2009). Impacts of stand age on soil C, N and P dynamics in a 40-year chromo sequence of alder-cardamon agroforestry stands of the Sikkim Himalayas. Pedobiologia 52: 401-414.

25. Singh, V., Wadhwanii, A.M. and Johari, B.M. (1996). Dictionary of Economic Plants in India. ICAR, New Delhi, pp. 298.

26. Singh, Y.B., Singh, J.K., Ladha, R.K., Gupta, O.P. and Pesuquin, E. (2005). Long term effects of organic input on yield and soil fertility in the rice and wheat rotation. Soil Sci. Soc. Am. J. 68: 845-853.

27. Taylor, L.L., Leake, J.R., Quirk, J., Hardy, K., Banwart, S.A. and Beerling, D.J. (2009). Biological weathering and the long-term carbon cycle: Integrating mycorrhizal evolution and function into the current paradigm. Geobiology 7: 171-191.

28. Tisdale, S.L., Nelson, W.L., Beaton, J.D. and Havlin, J. L. (1995). Soil Fertility and Fertilizer (5 $5^{\text {th }}$ ed.). Prentice-Hall of Indian, New Delhi, pp. 684.

29. UNDP (2010). Rajasthan Red Listed Medicinal Plants, http://envis.frlht.org/document s/rajasthan-medicinal-plants-conservation.pdf

30. Ventura, W. and Westanabe, I.0 (1984). Dynamics of nitrogen availability in lowland rice soils: The role of soil below plow layer and effects of moisture regimes. Philipp. J. Crop. Sci. 9: 135142.

31. Verma, V. (2008). Cultivation package for some desert medicinal plants. Ph.D. Thesis, J.N. Vyas University, Jodhpur, India.

32. Brantley, S. (2010). Weathering rock to regolith. Nat. Geosci. 3: 305-306. 